\title{
Digestibility and energy retention by young rabbits fed different levels of intake
}

\author{
Fernando Díaz Arca, Luis Manuel Pérez Alba, \\ Manuel Pérez Hernández* \\ Facultad de Veterinaria, Universidad de Córdoba, Avda. Medina Azahara, \\ 9, 14005 Córdoba, Spain
}

(Received 2 December 1997; accepted 3 February 1999)

\begin{abstract}
Four groups of eight young male rabbits ( $775 \mathrm{~g}$ of initial liveweight), individually penned in digestibility cages, were fed a standard diet at four levels of intake: ad libitum (AL), 60 , 40 and $10 \%$ of the AL intake. Digestibility of dietary dry matter, organic matter, crude protein, ether extract and ash did not differ between levels of intake. Only digestibility of neutral detergent fibre (NDF) was significantly lower for the group receiving $10 \%$ of the AL intake. Six of eight rabbits fed the $60 \%$ of the AL intake, and all the rabbits fed 40 or $10 \%$ of the AL intake lost body energy, although only those fed $10 \%$ of the AL allowance lost weight. The rabbits in the group fed AL gained $35 \mathrm{~g} \cdot \mathrm{d}^{-1}$ throughout the experiment. Efficiency of utilization of digestible energy for body energy retention was 0.436 . Digestible energy (DE) of this diet needed for zero energy change was $563 \mathrm{~kJ}$ DE.kg ${ }^{-0.75}$ liveweight. (C) Elsevier / Inra)
\end{abstract}

intake / digestibility / energy retention / rabbit

Résumé - Digestibilité et rétention énergétique d'une ration standard offerte à différents niveaux d'ingestion chez de jeunes lapins. La digestibilité d'une ration standard offerte à quatre niveaux d'ingestion a été déterminée avec quatre groupes de huit lapereaux mâles ayant un poids moyen de $775 \mathrm{~g}$. Les animaux ont été nourris avec un régime standard à différents niveaux d'ingestion : ad libitum (AL), 60, 40, et $10 \%$ de l'ingeré AL. Il n'y a pas eu de différences dues au niveau d'ingestion dans les valeurs de digestibilité de la matière sèche, de la matière organique, des matières azotées, de l'extrait éthéré et des cendres. Seule la digestibilité du NDF a été, de façon significative, inférieure dans le groupe à $10 \%$ de l'AL. Les lapereaux alimentés a ad libitum ont gagné $35 \mathrm{~g} \cdot \mathrm{j}^{-1}$ durant l'essai. Ceux alimentés à $60 \%$ et ceux recevant 40 et $10 \%$ de l'AL ont perdu de l'énergie corporelle, seuls ceux alimentés à $10 \%$ ont perdu du poids. L'énergie digestible de la ration nécessaire pour que le changement d'énergie corporelle ne se produise pas chez les lapereaux est de $563 \mathrm{~kJ} \cdot \mathrm{kg}^{0.75} \mathrm{de}$ poids. (C) Elsevier / Inra)

ingestion / digestibilité / retention énergétique / lapereaux

* Correspondence and reprints.

Tel.: 957 218746; fax: 957 218666; e-mail: vn1 pehem@lucano.uco.es 


\section{INTRODUCTION}

Digestibility is thought to change with level of intake in ruminant animals [1]. In rabbit feeding, feed may be offered ad libitum (AL) or on a restricted basis. Both systems have advantages and drawbacks [3, 11], but during some stages of the production cycle, restricted feeding is recommended as is, for example, young replacement stock. Perrier and Ouhayoun [17] conclude that growing rabbits can be restricted-fed during the beginning of the finishing period without affecting their performance if liberal feeding follows the restriction. Some authors $[2,10,12,13,16$, 21] have reported on effects of restricted feeding growing or adult rabbits on diet digestibility with variable results.

Data on energy retention by growing rabbits are scarce $[6,12,14,15,16,18]$. The aim of this note is to report the results of an experiment designed to determine digestibility and energy retention by growing rabbits offered a diet at four levels of intake.

\section{MATERIALS AND METHODS}

Forty-eight seven-week-old White New Zealand (WNZ) male rabbits (mean liveweight $775 \pm 5 \mathrm{~g}$ ) were studied. They had previously been penned in individual digestibility cages and fed ad libitum (AL) a standard diet during a 10-day period of adaptation $\left(\mathrm{g} \cdot \mathrm{kg}^{-1}\right.$ on air dry basis: wheat grain 385 , alfalfa hay 350 , soybean meal 100 , wheat straw $70,38 \%$ protein sunflower meal 60 , sepiolite 20 , dicalcium phosphate 6.6 , vitamin-mineral mixture 5, common salt 3 and calcium carbonate 0.4 ). All the ingredients were hammer-milled through a $3-\mathrm{mm}$ screen, mixed and steam pelleted through a $3.5-\mathrm{mm}$ die. This diet provided ( $\mathrm{g} \cdot \mathrm{kg}^{-1}$ on dry basis) crude protein (CP) 156, crude fibre (CF) 120 , neutral detergent fibre (NDF) 241, acid detergent fibre (ADF) 159 and gross energy (GE) $3.99 \mathrm{kca} \cdot \mathrm{g}^{-1}$ of dry matter (DM). Room temperature was $20 \pm 1{ }^{\circ} \mathrm{C}$ in a closed rabbitry with forced ventilation. Artificial light was provided 16 out of $24 \mathrm{~h}$.

On day 10 of the adaptation period, at 21.00 hours, the feed was withdrawn from all the rabbits. The next morning at 09.00 hours, the rabbits were weighed and assorted to one of six groups of eight animals. Then, at random, groups were either slaughtered (two groups) or switched to an allowance of 10,40 or $60 \%$ of their daily mean intake recorded during the previous 10-day period of $\mathrm{AL}$ feeding (one group to each level of intake). The rabbits in the remaining group were fed $\mathrm{AL}$.

During the following 15 days, intake was recorded daily and the faeces was collected for each rabbit. At 21.00 hours of day 15, feed was withdrawn. On day 16 at 09.00 hours, the rabbits, in turn, were weighed, stunned and weighed, bled (by cutting their throats) into a previously weighed container and weighed again. Any loss of blood was accounted for by the difference between weight after stunning and weight after bleeding. They were then skinned, open and all viscera were carefully removed. The gut was divided into stomach (with oesophagus), small intestine and large intestine and each of these organs was weighed with its content and again when emptied, then rinsed with tap water and dried. Gut content was added to the faeces. The bladder was carefully removed to prevent the spilling of urine and weighed, emptied and weighed again. Any loss of urine was accounted for by the difference between liveweight and weight after stunning. All viscera were dissected and weighed separately as well as the feet, skin and carcass (with skinned head). The weight data of the viscera and parts of the body of the rabbits were used for other purposes. The carcass (with head), viscera (with blood) and skin (with feet) were weighed, minced, mixed and samples taken to freeze-dry. The rabbits of the two groups slaughtered at the beginning of the experiment were handled in the same manner.

Feed and faeces were analysed for DM, ash and $\mathrm{CP}$, according to the AOAC [4] and ether extract (EE) according to Atkinson et al. [5]; NDF was performed according to Goering and Van Soest [9] using A-1278 type XI-A $\alpha$-amylase (Sigma, Saint Louis, USA). GE was measured in an adiabatic calorimeter (Parr, 1241). Freezedried rabbit parts were assayed for GE as described earlier.

The data of digestibility, liveweight change and retained energy were submitted to analysis of variance using the Duncan test to compare means. Linear regression was used to relate digestible energy intake (DEI) and retained energy (RE). DEI or RE scaled by initial metabolic liveweight (LW) and day were used alternatively as predictors. Statistical analyses were performed according to Steel and Torrie [19]. 


\section{RESULTS}

\subsection{Digestibility}

Five rabbits were removed from the experiment because of diarrhoea, one in the group fed AL and two in the groups fed $40 \%$ and $10 \%$ of the AL allowance (table I). Digestibility values of DM, organic matter (OM), CP, EE and energy were not different between groups, although there was a trend to lower values of apparent digestibility for $\mathrm{DM}, \mathrm{OM}$ and $\mathrm{GE}$ in rabbits from groups with lower intakes. This trend was reversed for EE digestibility. Only NDF digestibility was shown to be significantly lower in the most restricted group.

\subsection{Energy retention}

Daily intake of feed, body weight change and retained energy are shown in table II. Growth was normal in the group of rabbits fed AL (35 g.d $\left.\mathrm{d}^{-1}\right)$. Only rabbits fed $10 \%$ of $\mathrm{AL}$ allowance lost weight during the 15 days of the experiment. Rabbits fed 40,60 or $100 \%$ of AL intake increased body weight; however, all the rabbits fed 10 or $40 \%$ and most of those fed $60 \%$ of their previous AL intake had negative energy retention (ER) during the experimental 15 days.

On average, $60 \%$ of AL intake was not sufficient to keep growing rabbits on positive energy balance. In addition, constant body weight was not useful as an indicator of zero energy change in these animals.

The energy loss when fasting was calculated as $244 \mathrm{~kJ} \cdot \mathrm{kg}^{-0.75}$ of initial $\mathrm{LW} \cdot \mathrm{d}^{-1}$, efficiency for gaining energy was $0.436 \mathrm{~kJ}$ $\mathrm{RE} / \mathrm{kJ} \mathrm{DE}$, and DEI for zero energy change was $563 \mathrm{~kJ} \cdot \mathrm{kg}^{-0.75} \mathrm{LW} \cdot \mathrm{d}^{-1}$ from equation (1):

$$
\begin{gathered}
\mathrm{RE}=-244( \pm 19.3)+0.44( \pm 0.101) \mathrm{DEI} ; \\
r^{2}=0.955 ; P<0.001 ; \mathrm{df}=25 \quad \text { (1) }
\end{gathered}
$$

and equation (2):

$$
\begin{gathered}
\mathrm{DEI}=563( \pm 20.5)+2.19( \pm 0.11) \mathrm{RE} ; \\
r^{2}=0.955 ; P<0.001 ; \mathrm{df}=25
\end{gathered}
$$

\section{DISCUSSION}

\subsection{Digestibility}

Changes in digestibility in response to reduced levels of intake seem by no means to be predictable in rabbits. Various authors

\begin{tabular}{|c|c|c|c|c|c|c|}
\hline & \multicolumn{4}{|c|}{ Levels of intake } & \multirow[b]{2}{*}{ SEM } & \multirow[b]{2}{*}{$P$} \\
\hline & $\begin{array}{c}\mathrm{AL} \\
(n=7)\end{array}$ & $\begin{array}{c}60 \% \\
(n=8)\end{array}$ & $\begin{array}{c}40 \% \\
(n=6)\end{array}$ & $\begin{array}{c}10 \% \\
(n=6)\end{array}$ & & \\
\hline \multicolumn{7}{|l|}{ ADC of: } \\
\hline Dry matter & 0.74 & 0.73 & 0.72 & 0.70 & 0.021 & NS \\
\hline Organic matter & 0.76 & 0.75 & 0.74 & 0.73 & 0.012 & NS \\
\hline Crude protein & 0.85 & 0.87 & 0.86 & 0.85 & 0.008 & NS \\
\hline Ether extract & 0.57 & 0.58 & 0.59 & 0.61 & 0.140 & NS \\
\hline Neutral detergent fibre & $0.25^{\mathrm{a}}$ & $0.23^{\mathrm{a}}$ & $0.21^{\mathrm{a}}$ & $-0.13^{b}$ & 0.021 & 0.0013 \\
\hline Crude energy & 0.74 & 0.75 & 0.72 & 0.70 & 0.020 & NS \\
\hline
\end{tabular}
$[10,12,13,21]$ have found positive changes

Table I. Digestibility of a standard diet by groups of young rabbits fed at four levels of intake (ad libitum [AL], 60,40 or $10 \%$ of the ad libitum intake).

Results with a different letter in a row are significantly different $(P<0.005)$.

Real data of intake are in table II. ADC: apparent digestibility coefficient; SEM: standard error of the mean; NS: not significant. 
Table II. Means (with standard deviations) of intake, body weight change (BWC) and retained energy (RE) of young rabbits fed a standard diet at four levels of intake (ad libitum [AL], 60, 40 or $10 \%$ of the ad libitum intake).

\begin{tabular}{lcccc}
\hline & \multicolumn{4}{c}{ Levels of intake } \\
\cline { 2 - 5 } & $\begin{array}{c}\mathrm{AL} \\
(n=7)\end{array}$ & $\begin{array}{c}60 \% \\
(n=8)\end{array}$ & $\begin{array}{c}40 \% \\
(n=6)\end{array}$ & $\begin{array}{c}10 \% \\
(n=6)\end{array}$ \\
\hline Intake $\left(\mathrm{g} \cdot \mathrm{d}^{-1}\right)$ & $87 \pm 8.4^{\mathrm{a}}$ & $45 \pm 16^{\mathrm{b}}$ & $29 \pm 4.5^{\mathrm{c}}$ & $10 \pm 1.2^{\mathrm{d}}$ \\
BWC $\left(\mathrm{g} \cdot \mathrm{d}^{-1}\right)$ & $35 \pm 5.0^{\mathrm{a}}$ & $13 \pm 8.6^{\mathrm{b}}$ & $4.0 \pm 2.16^{\mathrm{c}}$ & $-22 \pm 7.4^{\mathrm{d}}$ \\
$\operatorname{RE}\left(\mathrm{kJ} \cdot \mathrm{d}^{-1}\right)$ & $228 \pm 52^{\mathrm{a}}$ & $9.0 \pm 66.9^{\mathrm{b}}$ & $-51 \pm 28^{\mathrm{c}}$ & $-183 \pm 19^{\mathrm{d}}$ \\
\hline
\end{tabular}

Results with a different letter in a row are significantly different $(P<0.005)$.

(significant or not) in dietary GE digestibility ranging from $1[21]$ to $9 \%[13]$ for growing rabbits or pregnant does [10]. In contrast, other authors have not found positive changes [16]. The positive response occurring with a certain delay after reducing the feed allowance has been observed by Arkhurst [2] but not by Lebas [10]. Age of the animals, type of diet, temperature in the rabbitry [18], degree and duration of the feeding restriction can possibly affect the response size. In this study we have only found decreased digestibility of dietary NDF when the diet was fed at $10 \%$ of the AL intake, rather than an increased digestibility.

The higher digestibility values obtained by restricting the intake must be due to longer digestion times in the different parts of the gut. Gidenne [8] showed that a higher content of dietary ADF leads to a faster passage rate (total mean retention time $4.6 \%$, higher for a diet with $6 \%$ less ADF, down from $22 \%$ ). From this a hypothesis can be made to explain the higher digestibility obtained in rabbits when fed restricted instead of AL amounts of feed: first, changes in digestibility with restricted feeding are caused by changes in rate of passage (a direct relationship exists between the level of feeding and the rate of passage). Second, the rate of passage has a minimum which is consistent with normal health. Diets richer in ADF have a higher rate of passage than diets with lower ADF levels [8]. The higher the rate of passage of a diet, the wider the room for decreasing it by lowering the level of feeding before the minimum is reached. A decreasing rate of passage would increase digestibility.

In the present experiment, the diet had only $14.5 \%$ of ADF on as-fed basis and the rate of passage should be closer to the hypothetical minimum, thus a not much higher digestibility should be expected by restricted-feeding it to rabbits.

\subsection{Energy retention}

The efficiency of utilisation of DE or metabolizable energy (ME) of feedstuffs for energy accretion in growing rabbits is affected by dietary characteristics (chemical composition of the absorbed energy [20]), by temperature in the rabbitry [18], by level of activity of the animals [18] and by the experimental and/or the statistical approach to measure or calculate it. Assuming similar levels of activity of the caged rabbits across published reports on this subject, it seems clear that dietary composition $[7,16]$ (directly influencing chemical composition of the absorbed energy) and rabbitry temperature [18] both affect the efficiency of utilisation of DE (or ME) for energy retention. The experimental approach (i.e. mea- 


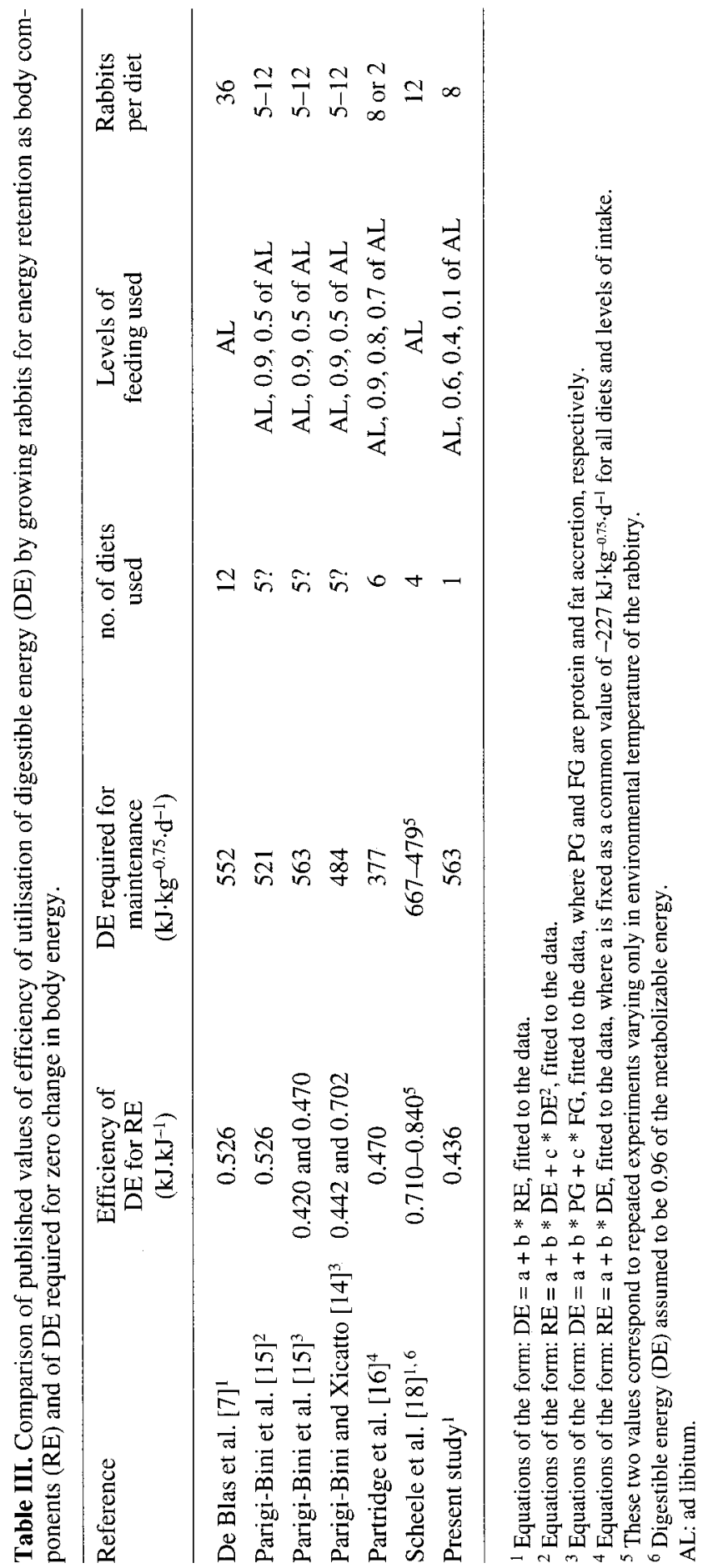


suring efficiency of utilisation of DE or ME below, above or below and above maintenance) can also influence the values of $\mathrm{DE}$ (or $\mathrm{ME}$ ) required for maintenance and of efficiency of DE (or ME) utilisation for energy retention, and this cause of variation may not always be taken into account when comparing and discussing results from this type of experiment.

Data from different authors who used feeding levels above maintenance $[7,16$, 18] and also slightly below maintenance [15], are compared in table $I I I$ with our data obtained with levels of intake ranging from well below maintenance to AL. The efficiency of utilisation of DE (or ME) for energy retention varies widely. Estimated values of DE for maintenance by de Blas et al. [7] and Parigi-Bini and Xiccato [14] do not differ from our data (table III). Values obtained by Scheele et al. [18] vary according to environmental temperatures (31-28 vs. $20-16^{\circ} \mathrm{C}$ ) around our value. In the present experiment, temperature of the rabbitry was always kept at $20^{\circ} \mathrm{C}$. Partridge et al. [16] reported lower values of DE required for maintenance.

By linear regressing DEI on RE (equation 1), the intercept $\left(-244 \mathrm{~kJ} \cdot \mathrm{kg}^{-1}\right.$ $\left.\mathrm{LW}^{0.75} \cdot \mathrm{d}^{-1}\right)$ is an estimate of the body energy loss when fasting. This loss is affected by rabbit activity and by the environmental temperature. Partridge et al. [16] gave a value of $-227 \mathrm{~kJ} \cdot \mathrm{kg}^{-1} \mathrm{LW}^{0.75} \cdot \mathrm{d}^{-1}$ for the same concept, common to all their rabbits, whatever the diet and level of feeding they received, which seems evident. This lower value of energy loss when fasting is consistent with the low value reported by Partridge et al. [16] for DE (ME/0.96) requirements for maintenance $\left(377 \mathrm{~kJ} \cdot \mathrm{kg}^{-1}\right.$ $\mathrm{LW}^{0.75} \cdot \mathrm{d}^{-1}$, table III). The efficiency of DE utilisation for maintenance calculated from data of these authors (227/377) is 0.60 , higher than their value of that for energy accretion (0.47) (table III). Our single datum of efficiency of DE utilisation is 0.44 (table $I I I)$, both for maintenance and for energy accretion, which is consistent with our experimental design. This could be considered as the result of two different experimental approaches to measure efficiency of utilisation of dietary DE by growing rabbits.

No other authors, among those considered here, give data of energy loss when fasting. However, by treating the equations of regression of RE on DEI given by de Blas et al.[7] and Scheele et al. [18] like algebraic ones and solving them for RE $\left(\mathrm{kJ}^{\mathrm{k}} \mathrm{kg}^{-1}\right.$ $\left.\mathrm{LW}^{0.75} \cdot \mathrm{d}^{-1}\right)$ when DEI $\left(\mathrm{kJ} \cdot \mathrm{kg}^{-1} \mathrm{LW}^{0.75} \cdot \mathrm{d}^{-1}\right)$ equals zero, a rough value of the body energy loss when fasting can be obtained. The value so calculated from de Blas et al. [7] is -290 and the values calculated from the data of Scheele et al. [18] were -340 and $-564 \mathrm{~kJ} \cdot \mathrm{kg}^{-1} \mathrm{LW}^{0.75}$ per day for rabbits kept at $31-28$ and $20-16{ }^{\circ} \mathrm{C}$, respectively, which seems to be very high.

More experiments, carefully designed to avoid confounding effects of temperature, activity (stress), sex, etc., are needed if sound data are to be obtained of the efficiency of utilisation of DE or ME for maintenance and/or growth. Those experiments should span the whole range of levels of feeding, from fasting to ad libitum, and take into account differences in digestible (or metabolizable) energy composition of the diets commonly used in rabbit production.

\section{ACKNOWLEDGEMENTS}

The agreement between Universidad de Córdoba and Diputación Provincial de Córdoba made possible the work reported here. The authors wish to thank the technical and working staff of the agricultural services of Diputación Provincial de Córdoba. They also wish to thank Mr. R. Gómez Lucena for providing the care of the experimental animals.

\section{REFERENCES}

[1] ARC, The Nutrient Requirements of Ruminant Livestock, Agricultural Research Council Commonwealth Agricultural Bureau, Slough, 1980, pp. 76-77. 
[2] Arkhurst G., Effect chez le lapin en croissance de l'addition de DL-methionine ou régime alimentaire, thèse $3^{e}$ cycle, Univ. Paris-VI, 1973.

[3] Arveaux P., Le rationemment alimentaire quantitatif en élevage cunicule, Cuniculture 18 (1991) 97-98.

[4] Association of Official Analytical Chemists, Official Methods of Analysis, $14^{\text {th }}$ edn., Association of Official Analytical Chemists, Washington, D.C., 1984.

[5] Atkinson T., Fowler V.R., Garton G.A., Lough A.K., A rapid method for the accurate determination of lipid in animal tissues, Analyst 97 (1972) 562-568.

[6] Blas de C., Santomá G., Valor nutritivo de los alimentos, in: Blas de C. (Ed.), Alimentación del conejo, Mundi Prensa, Madrid, 1984 pp. 59-65.

[7] Blas de J.C., Fraga M.J., Rodríguez J.M., Units for feed evaluation and requirements for commercially grown rabbits, J. Anim. Sci. 60 (1985) 1021-1028.

[8] Gidenne T., Measurement of the rate of passage in restricted fed rabbits: effect of dietary cell wall level on the transit of fibre particles of different sizes, Anim. Feed Sci. Technol. 42 (1993) 151-163.

[9] Goering P.V., Van Soest P., Forage fiber analyses (apparatus, reagents, procedures and some applications), in: Agricultural Handbook No. 73, ARS-USDA, Washington, D.C., 1970.

[10] Lebas F., Efficacité de la digestion chez la lapine adulte. Effects du niveau d'alimentation et du stade de gestation, Ann. Biol. Anim. Biochim. Biophys. 19 (1979) 969-973.

[11] Lebas F., Alimentation pratique des lapins en engraissement, Cuniculture 18 (1991) 273-281.

[12] Ledin I., A note on the effect of different feeding levels on the rate of digesta passage in rabbits, $\mathrm{Ph} . \mathrm{D}$. thesis, Sveriges Lautbruksuniversitet, Uppsala, Rapport 120.E:1-6, 1983.
[13] Ledin I., Effect of restricted feeding and realimentation on compensatory growth, carcass composition and organ growth in rabbit, Ann. Zootech. 33 (1984) 33-50.

[14] Parigi-Bini R, Xiccato G., Utilizzazione dell'energia e della proteina digerible neil coniglio in accrescimento, Conigliocoltura 23 (1986) 54-56.

[15] Parigi-Bini R., Xiccato G., Lanari D., Effect of nutritive level on body gain composition and on energy retention in growing rabbits, in: Moe P.W., Tyrrell H.F., Reynolds P.J. (Eds.), Proceedings of the 10th Symposium on Energy Metabolism of Farm Animals, Arlington, Virginia, 1985, pp. 106-109.

[16] Partridge G.G., Garthwaite P.H., Findlay M., Protein and energy retention by growing rabbits offered diets with increasing proportions of fibre, J. Agric. Sci. Camb. 112 (1989) 171-178.

[17] Perrier G., Ouhayoun J., Effets de différentes modalités de rationnement à l'engraissement sur les qualités bouchères du lapin, Cuniculture 130 (1996) 147-154

[18] Scheele C.W., van den Broek A., Hendricks F.A., Maintenance requirements and energy utilization of growing rabbits at different environmental temperatures, in: Moe P.W., Tyrrell H.F., Reynolds P.J., Proceedings of the 10th Symposium on Energy Metabolism of Farm Animals, Arlington, VA, 1985, pp. 202-205.

[19] Steel R.G.D., Torrie J.H., Bioestadística: principios y procedimientos, 2nd edn., McGrawHill, Bogotá, 1985

[20] Van Es A.J.H., Evaluation of the energy value of feeds: overall appreciation, in: Proceedings of the 7th Symposium on Energy Metabolism of Farm Animals, EAAP, Vichy, France, 1976, pp. 15-24.

[21] Xiccato G., Cinetto M., Zottle A., Dalle, Effetto del livello nutritivo e della categoria di conigli sull'efficienza digestiva e sul bilanzio azotato, Zootecnica e Nutritione Animale 18 (1992) $35-43$. 